\title{
Boletus aereus growing wild in Serbia: chemical profile, in vitro biological activities, inactivation and growth control of food-poisoning bacteria in meat
}

\author{
Dejan S. Stojković ${ }^{1} \cdot$ Filipa S. Reis $^{2} \cdot$ Ana Ćirić $^{1} \cdot$ Lillian Barros $^{2}$ - Jasmina Glamočlija ${ }^{1}$. \\ Isabel C. F. R. Ferreira ${ }^{2} \cdot$ Marina Soković $^{1}$
}

Revised: 14 January 2015 / Accepted: 22 April 2015 /Published online: 6 May 2015

(C) Association of Food Scientists \& Technologists (India) 2015

\begin{abstract}
Boletus aereus Bull. is a bolete, an edible mushroom frequently consumed all over the globe as a delicate mushroom, especially in Serbia, Portugal, Basque Country, Navarre, France and Italy. B. aereus was showed to be rich in carbohydrates $(82.58 \mathrm{~g} / 100 \mathrm{~g} \mathrm{dw})$, followed by proteins $(7.86 \mathrm{~g} / 100 \mathrm{~g} \mathrm{dw})$, ash $(6.20 \mathrm{~g} / 100 \mathrm{~g} \mathrm{dw})$ and fat $(3.36 \mathrm{~g} / 100 \mathrm{~g} \mathrm{dw})$. The most abundant sugar was identified as trehalose $(11.28 \mathrm{~g} / 100 \mathrm{~g} \mathrm{dw})$; three tocopherol isoforms $(\alpha-, \beta$ - and $\delta$-tocopherols) were detected. Unsaturated fatty acids predominated over saturated fatty acids, with oleic and linoleic acids as the most dominant ones. $p$-Hydroxybenzoic $(8.95 \mu \mathrm{g} / 100 \mathrm{~g} \mathrm{dw}), p$-coumaric $(7.32 \mu \mathrm{g} / 100 \mathrm{~g} \mathrm{dw})$ and cinnamic $(5.91 \mu \mathrm{g} / 100 \mathrm{~g} \mathrm{dw})$ acids were quantified, as also four organic acids: oxalic $(0.69 \mathrm{~g} / 100 \mathrm{~g} \mathrm{dw})$, citric $(0.59 \mathrm{~g} / 100 \mathrm{~g} \mathrm{dw})$, quinic $(0.34 \mathrm{~g} / 100 \mathrm{~g} \mathrm{dw})$, and fumaric $(0.20 \mathrm{~g} / 100 \mathrm{~g} \mathrm{dw})$ acids. The mushroom methanolic extract
\end{abstract}

Research highlights $\cdot$ B. aereus was a rich source of carbohydrates and proteins.

- Oleic and linoleic acid were the main fatty acids.

- $p$-Coumaric, $p$-hydroxybenzoic, and cinnamic acids were found.

- The extract possessed antimicrobial and antioxidant activities.

- The extract regulated the growth of contaminant bacteria in meat.

Dejan S. Stojković and Filipa S. Reis contributed equally to this work.

Isabel C. F. R. Ferreira

iferreira@ipb.pt

Marina Soković

mris@ibiss.bg.ac.rs

1 Institute for Biological Research "Siniša Stanković", University of Belgrade, Bulevar Despota Stefana 142, 11000 Belgrade, Serbia

2 Montain Research Centre (CIMO), ESA, Polytechnic Institute of Bragança, Campus de Santa Apolónia, Ap. 1172, 5301-855 Bragança, Portugal showed in vitro antioxidant and antimicrobial activities, and successively inhibited the growth of meat contaminant bacteria, both at $25^{\circ} \mathrm{C}$ and $4{ }^{\circ} \mathrm{C}$, after 7 days of inoculation.

Keywords Boletus aereus - Chemical composition · Antioxidant $\cdot$ Antimicrobial $\cdot$ Meat preservatives

\section{Introduction}

Boletus aereus Bull. is a member of the Boletaceae family, this mushroom has tubes and pores, instead of gills beneath its cap. Cap diameter is up to $25 \mathrm{~cm}$ wide, while stipes is up to $15 \mathrm{~cm}$ high. Spores are olivaceous (Hadžić 2012). Several Boletus species growing wild in Portugal have been previously chemically characterized and their antioxidant features have also been determined (Heleno et al. 2011).

Different compounds present in mushrooms may have beneficial effects on human health (Ren, et al. 2012; Reis et al. 2012a; Stojković et al. 2013a; Popović et al. 2013), but may also posses antimicrobial food preserving properties (Reis et al. 2012a; Stojković et al. 2013b). Among bioactive constituents in medicinal and edible mushrooms, tocopherols, fatty acids, organic acids and phenolic compounds, are among the most frequently reported. Bioactive properties of tocopherols include antioxidant capacity with ability to prevent diseases correlated with increased formation of free radicals and oxidative stress (Ferreira et al. 2009; Carocho and Ferreira 2013). Antioxidant activity is related to inhibition of the oxidation of lipids, proteins, DNA or other molecules that occurs by blocking the propagation step in oxidative chain reactions (Carocho and Ferreira 2013).

Antimicrobial activity of mushroom extracts and compounds are also very well documented, highlighting different species as natural sources of promising antimicrobial 
agents (Alves et al. 2013). Nowadays, consumers are aware of the health concerns regarding food additives (antimicrobial and antioxidant); the health benefits of "natural" and "traditional" foods, processed without any addition of chemical preservatives, are becoming more attractive (Franz et al. 2010). The present study has the potential of practical applications to food industry, regarding preservation of meat with a natural mushroom extract.

In our continuing search for mushroom compounds and extracts with bioactive properties (Reis et al. 2012a; Heleno et al. 2011; Stojković et al. 2013b), fruiting bodies of wild growing Boletus aereus Bull. were evaluated for their nutritional value, chemical composition (free sugars, fatty acids, tocopherols, organic acids and phenolic compounds), antioxidant, antibacterial and antifungal properties. Furthermore, the potential of the methanolic extract as antibacterial preserving agent in pork meat was studied.

\section{Material and methods}

\section{Samples}

The material of wild growing Boletus aereus Bull. was collected from mountain Divcibare, Serbia, in autumn 2012, and authenticated by Dr. Jasmina Glamočlija (Institute for Biological Research). A voucher specimen has been deposited at the Fungal Collection Unit of the Mycological Laboratory, Department for Plant Physiology, Institute for Biological Research "Siniša Stanković", Belgrade, Serbia, under number BA-DS-2012.

\section{Standards and reagents}

Acetonitrile $99.9 \%$, n-hexane $95 \%$ and ethyl acetate $99.8 \%$ were of HPLC grade from Fisher Scientific (Lisbon, Portugal). The fatty acids methyl ester (FAME) reference standard mixture 37 (standard 47885-U) was purchased from Sigma (St. Louis, MO, USA), as also were other individual fatty acid isomers, trolox (6-hydroxy-2,5,7,8tetramethylchroman-2-carboxylic acid), tocopherol and sugar standards. Phenolic compound standards were from Extrasynthese (Genay, France). Racemic tocol, $50 \mathrm{mg} / \mathrm{mL}$, was purchased from Matreya (Pleasant Gap, PA, USA). 2,2-Diphenyl-1- picrylhydrazyl (DPPH) was obtained from Alfa Aesar (Ward Hill, MA, USA). Mueller-Hinton agar (MH) and malt agar (MA) were obtained from the Institute of Immunology and Virology, Torlak (Belgrade, Serbia). Dimethylsulfoxide (DMSO) (Merck KGaA, Darmstadt, Germany) was used as a solvent. Water was treated in a Milli-Q water purification system (TGI Pure Water Systems, Greenville, SC, USA).

\section{Chemical profile}

\section{Nutritional value and free sugars}

The samples were analysed for chemical composition (moisture, proteins, fat, carbohydrates and ash) using the AOAC procedures (AOAC 1995).

Free sugars were determined by high performance liquid chromatography coupled to a refraction index detector (HPLC-RI, Knauer, Smartline system 1000; Berlin, Germany), after extraction and analysis procedures previously described by the authors (Heleno et al. 2009) using melezitoze as internal standard (IS). The compounds were identified by chromatographic comparisons with authentic standards. Quantification was performed using the internal standard method and sugar contents were further expressed in $\mathrm{g}$ per $100 \mathrm{~g}$ of dry weight $(\mathrm{dw})$.

\section{Bioactive compounds}

Fatty acids were determined by gas-liquid chromatography (DANI 1000; Contone, Switzerland) with flame ionization detection (GC-FID)/capillary column as described previously by the authors (Heleno et al. 2009). The results were expressed in relative percentage of each fatty acid.

Tocopherols were determined following a procedure previously described by the authors (Heleno et al. 2010) using HPLC-fluorescence (Knauer, Smartline system 1000, FP2020; Jasco, Easton, MD, USA). Quantification was based on the fluorescence signal response of each standard, using the IS (tocol) method and by using calibration curves obtained from commercial standards of each compound. The results were expressed in $\mu \mathrm{g}$ per $100 \mathrm{~g}$ of dry weight (dw).

Organic acids were determined by ultrafast liquid chromatography coupled to a photodiode array detector (UFLC-PAD, Shimadzu Coperation, Kyoto, Japan), following a procedure previously described by the authors (Barros et al. 2013). The organic acids found were quantified by comparison of the area of their peaks recorded at $215 \mathrm{~nm}$ with calibration curves obtained from commercial standards of each compound. The results were expressed in g per $100 \mathrm{~g}$ of dry weight (dw).

Phenolic compounds were determined using a Shimadzu 20A series ultra fast liquid chromatograph (UFLC, Shimadzu Coperation, equipment described above) as previously described by using $280 \mathrm{~nm}$ and $370 \mathrm{~nm}$ as preferred wavelengths, according to a procedure previously described by the authors (Reis et al. 2012b). The phenolic compounds were characterized according to their UV and retention times, and comparison with authentic standards. For quantitative analysis, calibration curves were prepared from different standard compounds. The results were expressed in $\mathrm{mg}$ per $100 \mathrm{~g}$ of dry weight $(\mathrm{dw})$. 


\section{Extract preparation for bioactivity evaluation}

Each sample $(\sim 5 \mathrm{~g})$ was extracted by stirring with $150 \mathrm{~mL}$ of methanol $\left(25^{\circ} \mathrm{C}\right.$ at $\left.150 \mathrm{rpm}\right)$ for $1 \mathrm{~h}$ and subsequently filtered through Whatman No. 4 paper. The residue was then extracted with an additional portion of methanol. The combined methanolic extracts were evaporated under reduced pressure (rotary evaporator Büchi R-210; Flawil, Switzerland) to dryness. The extract was redissolved in $i$ ) methanol (final concentration $20 \mathrm{mg} / \mathrm{mL}$ ) for antioxidant activity assays, ii) $5 \%$ DMSO containing $0.02 \%$ Tween 80 (final concentration $1.5 \mathrm{mg} / \mathrm{mL}$ ) for antimicrobial activity assays and iii) sterilized distilled water containing $0.02 \%$ Tween 80 (final concentration $1.5 \mathrm{mg} / \mathrm{mL}$ ) for meat preserving properties. The final solutions were further diluted to different concentrations for evaluation of distinct bioactivity using in vitro assays.

\section{In vitro bioactive properties}

\section{Antioxidant properties}

Successive dilutions were made from the stock solution and submitted to different in vitro assays to evaluate the antioxidant activity of the samples (Heleno et al. 2010). The sample concentrations providing $50 \%$ of antioxidant activity or 0.5 of absorbance $\left(\mathrm{EC}_{50}\right)$ were calculated from the graphs of antioxidant activity percentages (DPPH, $\beta$-carotene/linoleate and TBARS assays) or absorbance at $690 \mathrm{~nm}$ (ferricyanide/ Prussian blue assay) against sample concentrations. Trolox was used as standard.

Folin-ciocalteu assay The extract solution $(1 \mathrm{~mL})$ was mixed with Folin-Ciocalteu reagent $(5 \mathrm{~mL}$, previously diluted with water $1: 10, \mathrm{v} / \mathrm{v})$ and sodium carbonate $(75 \mathrm{~g} / \mathrm{L}, 4 \mathrm{~mL})$. The tubes were vortex mixed for $15 \mathrm{~s}$ and allowed to stand for $30 \mathrm{~min}$ at $40^{\circ} \mathrm{C}$ for colour development. Absorbance was then measured at $765 \mathrm{~nm}$ (Analytikjena spectrophotometer; Jena, Germany). Gallic acid was used to obtain the standard curve and the reduction of Folin-Ciocalteu reagent by the samples was expressed as mg of gallic acid equivalents (GAE) per $g$ of extract.

Reducing power or ferricyanide/Prussian blue assay The extract solutions with different concentrations $(0.5 \mathrm{~mL})$ were mixed with sodium phosphate buffer $(200 \mathrm{mmol} / \mathrm{L}, \mathrm{pH}$ 6.6, $0.5 \mathrm{~mL})$ and potassium ferricyanide $(1 \% \mathrm{w} / \mathrm{v}, 0.5 \mathrm{~mL})$. The mixture was incubated at $50{ }^{\circ} \mathrm{C}$ for $20 \mathrm{~min}$, and trichloroacetic acid $(10 \% \mathrm{w} / \mathrm{v}, 0.5 \mathrm{~mL})$ was added. The mixture $(0.8 \mathrm{~mL})$ was poured in the 48 wells plate, the same with deionised water $(0.8 \mathrm{~mL})$ and ferric chloride $(0.1 \% \mathrm{w} / \mathrm{v}, 0.16 \mathrm{~mL})$, and the absorbance was measured at $690 \mathrm{~nm}$ in ELX800 Microplate Reader (Bio-Tek Instruments, Inc; Winooski, VT, USA).
DPPH radical-scavenging activity assay This methodology was performed using the Microplate Reader mentioned above. The reaction mixture was made in a 96 wells plate and consisted of $30 \mu \mathrm{L}$ of a concentration range of the extract and $270 \mu \mathrm{L}$ methanol containing DPPH radicals $\left(6 \times 10^{-5} \mathrm{~mol} / \mathrm{L}\right)$. The mixture was left to stand for $30 \mathrm{~min}$ in the dark, and the absorption was measured at $515 \mathrm{~nm}$. The radical scavenging activity (RSA) was calculated as a percentage of DPPH discolouration using the equation: \% $\mathrm{RSA}=\left[\left(\mathrm{A}_{\mathrm{DPPH}}-\mathrm{A}_{\mathrm{S}}\right) / \mathrm{A}_{\mathrm{DPPH}}\right] \times 100$, where $\mathrm{A}_{\mathrm{S}}$ is the absorbance of the solution containing the sample and $A_{D P P H}$ is the absorbance of the DPPH solution.

Inhibition of $\beta$-carotene bleaching or $\beta$-carotene/linoleate assay A solution of $\beta$-carotene was prepared by dissolving $\beta$-carotene $(2 \mathrm{mg})$ in chloroform $(10 \mathrm{~mL})$. Two millilitres of this solution were pipetted into a round-bottom flask. The chloroform was removed at $40^{\circ} \mathrm{C}$ under vacuum and linoleic acid $(40 \mathrm{mg})$, Tween 80 emulsifier $(400 \mathrm{mg})$, and distilled water $(100 \mathrm{~mL})$ were added to the flask with vigorous shaking. Aliquots $(4.8 \mathrm{~mL})$ of this emulsion were transferred into test tubes containing $0.2 \mathrm{~mL}$ of a concentration range of the extract. The tubes were shaken and incubated at $50^{\circ} \mathrm{C}$ in a water bath. As soon as the emulsion was added to each tube, the zero time absorbance was measured at $470 \mathrm{~nm}$. $\beta$-Carotene bleaching inhibition was calculated using the following equation: Absorbance after $2 \mathrm{~h}$ of assay/initial absorbance) $\times 100$.

Thiobarbituric acid reactive substances (TBARS) assay Porcine (Sus scrofa) brains were obtained from official slaughtering animals, dissected, and homogenized with a Polytron in ice cold Tris-HCl buffer ( $20 \mathrm{mM}, \mathrm{pH} 7.4)$ to produce a $1: 2 w / v$ brain tissue homogenate which was centrifuged at $3000 \mathrm{~g}$ for $10 \mathrm{~min}$. An aliquot $(100 \mu \mathrm{L})$ of the supernatant was incubated with $200 \mu \mathrm{L}$ samples of a concentration range of the extract in the presence of $\mathrm{FeSO}_{4}(10 \mathrm{mM} ; 100 \mu \mathrm{L})$ and ascorbic acid $(0.1 \mathrm{mM} ; 100 \mu \mathrm{L})$ at $37^{\circ} \mathrm{C}$ for $1 \mathrm{~h}$. The reaction was stopped by the addition of trichloroacetic acid $(28 \% \mathrm{w} / \mathrm{v}$, $500 \mu \mathrm{L}$ ), followed by thiobarbituric acid (TBA, $2 \%, w / v$, $380 \mu \mathrm{L}$ ), and the mixture was then heated at $80^{\circ} \mathrm{C}$ for $20 \mathrm{~min}$. After centrifugation at $3000 \mathrm{~g}$ for $10 \mathrm{~min}$ to remove the precipitated protein, the color intensity of the malondialdehyde (MDA)-TBA complex in the supernatant was measured by its absorbance at $532 \mathrm{~nm}$. The inhibition ratio (\%) was calculated using the following formula: Inhibition ratio $(\%)=[(\mathrm{A}-\mathrm{B}) / \mathrm{A}] \times 100 \%$, where $\mathrm{A}$ and $\mathrm{B}$ were the absorbance of the control and the sample solution, respectively.

\section{Antimicrobial properties}

The following bacteria were used: Escherichia coli (ATCC 35210), Pseudomonas aeruginosa (ATCC 27853), 
Salmonella Typhimurium (ATCC 13311), Enterobacter cloacae (ATCC 35030), Staphylococcus aureus (ATCC 6538), Bacillus cereus (clinical isolate), Micrococcus flavus (ATCC 10240), and Listeria monocytogenes (NCTC 7973).

For the antifungal bioassays, microfungi were used: Aspergillus fumigatus (1022), Aspergillus ochraceus (ATCC 12066), Aspergillus versicolor (ATCC 11730), Aspergillus niger (ATCC 6275), Penicillium funiculosum (ATCC 36839), Penicillium ochrochloron (ATCC 9112), Trichoderma viride (IAM 5061), and Penicillium aurantiogriseum (food isolate). The organisms were obtained from the Mycological Laboratory, Department of Plant Physiology, Institute for Biological Research "Siniša Stanković", Belgrade, Serbia.

In order to investigate the antimicrobial activity of the B. aereus methanolic extract, a modified microdilution technique was used (CLSI 2009). The bacterial cells and fungal spore suspension was adjusted with sterile saline to a concentration of approximately $1.0 \times 10^{5}$ in a final volume of $100 \mu \mathrm{L}$ per well. The inocula were stored at $4{ }^{\circ} \mathrm{C}$ for further use. Dilutions of the inocula were cultured on Müller-Hinton agar for bacteria and solid Malt Agar for fungi to verify the absence of contamination and to check the validity of the inoculum.

Minimum inhibitory concentration (MIC) determinations were performed by a serial dilution technique using 96-well microtiter plates. The minimum bactericidal concentrations (MBCs) and minimum fungicidal concentrations (MFCs) were determined by serial subcultivation of a $2 \mu \mathrm{L}$ sample into microtiter plates containing $100 \mu \mathrm{L}$ of broth per well and further incubation for $48 \mathrm{~h}$ at $37{ }^{\circ} \mathrm{C}$ or $72 \mathrm{~h}$ at $28^{\circ} \mathrm{C}$. The lowest concentration with no visible growth was defined as MBC/MFC, respectively, indicating $99.5 \%$ killing of the original inoculum. $5 \%$ DMSO was used as a negative control.

\section{In situ antibacterial preservation of pork meat}

\section{Pork meat and preparation of pork meat medium}

Milled pork meat was purchased from the local supermarket. Pieces of pork meat $(10 \mathrm{~g})$ were added to $90 \mathrm{~mL}$ of distilled water and blended to make homogenous mass. The pork meat solution was then sterilized by autoclaving at $70{ }^{\circ} \mathrm{C}$, for $20 \mathrm{~min}$. After cooling, $\mathrm{pH}$ value of the pork meat solution was determined to be 6.7. Serial dilutions of the pork meat solution were made and cultured on MH and MA plates, kept at $37{ }^{\circ} \mathrm{C}$ and $25^{\circ} \mathrm{C}$, respectively, in order to investigate possible bacterial or fungal contaminants after autoclaving (Brand, City, and Country).

\section{In situ antibacterial assay in pork meat medium}

Different concentrations of the mushroom extract were added to the pork meat medium to achieve final concentrations in range of $0.2-3.2 \mathrm{mg} / \mathrm{mL}$ respectively. The controls contained pork meat medium but not mushroom extract. The flasks were homogenized for $30 \mathrm{~s}$ to ensure mixing of the extract compounds with pork meat medium.

The modified method for antimicrobial food preserving properties was used as previously described by authors (Bukvički et al. 2014; Stojković et al. 2013b). The pork meat medium was inoculated with $\sim 10^{6}$ cells of Staphylococcus aureus, Listeria monocytogenes, Escherichia coli and Salmonella Typhimurium that had been prepared by growing overnight bacterium at $37{ }^{\circ} \mathrm{C}$ in TSB medium. Cells suspension was adjusted with sterile saline to approximately $1 \times 10^{6}$ cells per $100 \mu \mathrm{L}$ of pork meat medium. Experimental microplates were divided in two groups: one group was kept at $25{ }^{\circ} \mathrm{C}$ and the other at $4{ }^{\circ} \mathrm{C}$. Both groups contained equal amount of mushroom extract. The inhibition percentage at $25{ }^{\circ} \mathrm{C}$ (1)and $4{ }^{\circ} \mathrm{C}$ (2) was calculated by optical density measured by ELISA plate reader (Tecan Austria, GmbHAustria, Ependorf-AG, Germany) using the following equations:

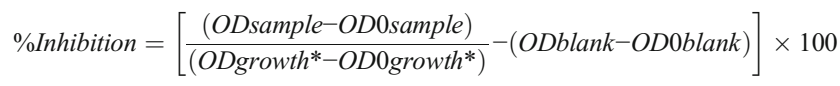

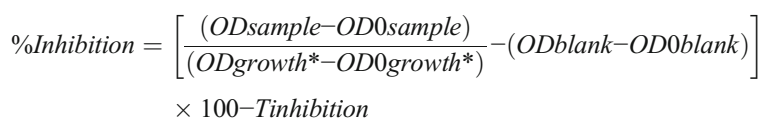

where OD0sample and ODsample corresponded to the absorbance at $612 \mathrm{~nm}$ of the strain growth in the presence of the extract before and after incubation, respectively; OD0blank and ODblank corresponded to the broth medium with dissolved compound before and after incubation, respectively; and OD0growth* and ODgrowth* to the strain growth in the absence of the extract compound before and after incubation at $25{ }^{\circ} \mathrm{C}$, respectively. Tinhibition corresponded to temperature inhibition of bacteria tested at $4{ }^{\circ} \mathrm{C}$, measured according to the formula (3):

TInhibition $=100-\left(\frac{\text { ODTgrowth } \times 100}{\text { ODT0growth }}\right)$

where ODT0growth and ODTgrowth presented the growth of bacteria tested at $4{ }^{\circ} \mathrm{C}$ in liquid medium, before and after incubation, respectively. The results were further presented as growth inhibition concentrations (GIC) that cause $50 \%$ retardation of bacterial growth. The $\mathrm{GIC}_{50}$ was calculated as follows: inhibition percentage was calculated; a linear regression was made using the concentrations and respective $\%$ of inhibition that are immediately before and after the $50 \%$ of inhibition; using the equation curve the value of $50 \%$ of inhibition was obtained. 


\section{Results and discussion}

\section{Chemical composition of $B$. aereus}

Nutrients and sugars composition of $B$. aereus are presented in Table 1. B. aereus showed to be rich in carbohydrates (82.58 g/100 g dw), which were the most abundant macronutrients. Proteins were present at $7.86 \mathrm{~g} / 100 \mathrm{~g} \mathrm{dw}$. Energetic value was established to be $392 \mathrm{kcal} / 100 \mathrm{~g}$ dw. A sample of $B$. aereus growing in Portugal was also reported to have carbohydrates as the most abundant macronutrient (Heleno et al. 2011). The carbohydrates in mushrooms comprise various compounds: sugars (monosaccharides, their derivatives and oligosaccharides) and both reserve and structural polysaccharides (glycans) (Stojković et al. 2013b, 2014a, b). Trehalose was the most abundant sugar with $11.28 \mathrm{~g} / 100 \mathrm{~g}$ $\mathrm{dw}$, followed by mannitol $(6.22 \mathrm{~g} / 100 \mathrm{~g} \mathrm{dw})$, fructose $(3.17 \mathrm{~g} /$ $100 \mathrm{~g} \mathrm{dw})$ and rhamnose $(0.43 \mathrm{~g} / 100 \mathrm{~g} \mathrm{dw})$. Trehalose $(4.65 \mathrm{~g} /$ $100 \mathrm{~g} \mathrm{dw})$ and mannitol (1.34 g/100 g dw) were also detected in a $B$. aereus sample from Portugal previously studied (Heleno et al. 2011). Our data are in accordance to previous investigations reporting mannitol and trehalose as the main representatives of alcoholic sugars and oligosaccharides generally present in mushrooms (Kalač 2013).

Quantitative and qualitative analysis of $B$. aereus bioactive compounds revealed the presence of fatty acids, tocopherols, and organic and phenolic acids (Table 2). Regarding fatty acids composition, oleic acid was the most abundant, followed by linoleic and palmitic acids. Previous reports on fatty acids composition (Hanuš et al. 2008; Heleno et al. 2011) of $B$. aereus are in accordance to those reported herein. High content of linoleic and oleic acids were also recorded in B. aereus originating from Portugal (Heleno et al. 2011). There is extensive scientific evidence showing that modulation of dietary fat composition affects blood-lipid concentrations. Regarding oleic acid, or monounsaturated fatty acids (MUFA), the most noticeable effects come from

Table 1 Nutrients and sugars composition of Boletus aereus on dry weight basis (mean $\pm \mathrm{SD}$ )

\begin{tabular}{lr}
\hline & Boletus aereus \\
\hline Ash $(\mathrm{g} / 100 \mathrm{~g})$ & $6.20 \pm 0.04$ \\
Proteins $(\mathrm{g} / 100 \mathrm{~g})$ & $7.86 \pm 0.11$ \\
Fat $(\mathrm{g} / 100 \mathrm{~g})$ & $3.36 \pm 0.45$ \\
Carbohydrates $(\mathrm{g} / 100 \mathrm{~g})$ & $82.58 \pm 0.42$ \\
Energy $(\mathrm{kcal} / 100 \mathrm{~g})$ & $392.00 \pm 1.48$ \\
Rhamnose $(\mathrm{g} / 100 \mathrm{~g})$ & $0.43 \pm 0.01$ \\
Fructose $(\mathrm{g} / 100 \mathrm{~g})$ & $3.17 \pm 0.13$ \\
Trehalose $(\mathrm{g} / 100 \mathrm{~g})$ & $11.28 \pm 0.31$ \\
Mannitol $(\mathrm{g} / 100 \mathrm{~g})$ & $6.22 \pm 0.26$ \\
Total sugars $(\mathrm{g} / 100 \mathrm{~g})$ & $21.10 \pm 0.69$ \\
\hline
\end{tabular}

Table 2 Bioactive compounds of Boletus aereus on dry weight basis $($ mean \pm SD)

\begin{tabular}{lc}
\hline & Boletus aereus \\
\hline C16:0 & $13.17 \pm 0.07$ \\
C18:0 & $1.84 \pm 0.00$ \\
C18:1n9 & $41.78 \pm 0.08$ \\
C18:2n6 & $40.02 \pm 0.03$ \\
SFA (relative percentage) & $17.23 \pm 0.09$ \\
MUFA (relative percentage) & $42.54 \pm 0.06$ \\
PUFA (relative percentage) & $40.23 \pm 0.03$ \\
$\alpha$-Tocopherol $(\mu \mathrm{g} / 100 \mathrm{~g})$ & $5.92 \pm 1.37$ \\
$\beta$-Tocopherol $(\mu \mathrm{g} / 100 \mathrm{~g})$ & $29.13 \pm 5.20$ \\
$\gamma$-Tocopherol $(\mu \mathrm{g} / 100 \mathrm{~g})$ & $101.70 \pm 21.58$ \\
$\delta$-Tocopherol $(\mu \mathrm{g} / 100 \mathrm{~g})$ & $\mathrm{nd}$ \\
Total tocopherols $(\mu \mathrm{g} / 100 \mathrm{~g})$ & $136.75 \pm 28.15$ \\
Oxalic acid $(\mathrm{g} / 100 \mathrm{~g})$ & $0.69 \pm 0.01$ \\
Quinic acid $(\mathrm{g} / 100 \mathrm{~g})$ & $0.34 \pm 0.11$ \\
Citric acid $(\mathrm{g} / 100 \mathrm{~g})$ & $0.59 \pm 0.03$ \\
Fumaric acid $(\mathrm{g} / 100 \mathrm{~g})$ & $0.20 \pm 0.00$ \\
Total sugars $(\mathrm{g} / 100 \mathrm{~g})$ & $1.83 \pm 0.15$ \\
$p$-Hydroxybenzoic acid $(\mathrm{mg} / 100 \mathrm{~g})$ & $0.89 \pm 0.12$ \\
$p$-Coumaric acid $(\mathrm{mg} / 100 \mathrm{~g})$ & $0.73 \pm 0.07$ \\
Cinnamic acid $(\mathrm{mg} / 100 \mathrm{~g})$ & $0.59 \pm 0.04$ \\
Total $(\mathrm{mg} / 100 \mathrm{~g})$ & $1.63 \pm 0.19$ \\
\hline &
\end{tabular}

Main fatty acids: C16:0 (Palmitic acid), C18:0 (Stearic acid), C18:1n9 (Oleic acid) and C18:2n6 (Linoleic acid); 20 more fatty acids were identified in trace amounts

SFA saturated fatty acids, MUFA monounsaturated fatty acids, PUFA polyunsaturated fatty acids, $n d$ not detected

studies where the substitution of saturated fat with oleic acid has been tested. Isocaloric replacement of about $5 \%$ of energy from saturated fatty acids by oleic acid (or PUFA) has been estimated to reduce coronary heart disease risk by $20-40 \%$ mainly via LDL-cholesterol reduction (Kris-Etherton 1999). Thus, B. aereus could be a useful source for intake of healthbeneficial unsaturated fatty acids such as oleic and linoleic acids. Three tocopherol isoforms were detected in our sample highlighting $\gamma$-tocopherol as the most abundant one $(101.70 \mu \mathrm{g} / 100 \mathrm{~g} \mathrm{dw}) ; \beta$ - and $\alpha$-tocopherols were also detected but in lower amounts. $\gamma$-Tocopherol was previously established to be the most abundant tocopherol isoform in B. aereus (Heleno et al. 2011). The literature on bioactivity of tocopherol isoforms other than $\alpha$-tocopherol is limited. It was previously indicated that $\gamma$-tocopherol, like $\alpha$-tocopherol, has anti-inflammatory properties in addition to antioxidant capabilities (Hensley et al. 2004). A recent study highlighted the importance of $\gamma$-tocopherol in neuroprotection of the brain (Morris et al. 2014). B. aereus is a good source of $\gamma$-tocopherol, which plays an important role in human health as antioxidant, anti-inflammatory and neuroprotective agent. 
$B$. aereus contained four organic acids with the highest content of oxalic acid $(0.69 \mathrm{~g} / 100 \mathrm{~g} \mathrm{dw})$, followed by citric $(0.59 \mathrm{~g} / 100 \mathrm{~g} \mathrm{dw})$, quinic $(0.34 \mathrm{~g} / 100 \mathrm{~g} \mathrm{dw})$, and fumaric $(0.20 \mathrm{~g} / 100 \mathrm{~g} \mathrm{dw})$ acids. Interestingly, it did not show malic acid, previously reported as the most abundant organic acid in B. aereus growing wild in Portugal. Nevertheless, oxalic acid, determined as the most abundant organic acid in the specimen of the present study, was also quantified in the sample studied previously (Barros et al. 2013).

Regarding phenolic compounds, $p$-hydroxybenzoic $(0.89 \mathrm{mg} / 100 \mathrm{~g} \mathrm{dw}), p$-coumaric $(0.73 \mathrm{mg} / 100 \mathrm{~g} \mathrm{dw})$ and cinnamic $(0.59 \mathrm{mg} / 100 \mathrm{~g} \mathrm{dw})$ acids were quantified in the studied sample. Heleno et al. (2011), also reported $p$-hydroxybenzoic and $p$-coumaric acids in $B$. aereus, while cinnamic acid was not detected. Therefore, determination of mushroom nutrients and non-nutrients (secondary metabolites) is essential for wild growing samples, since some edible species can grow under different environmental conditions, which might have impact on chemical composition. This study describes, for the first time, macronutrients content and bioactive compounds in B. aereus growing wild in Serbia.

\section{In vitro antioxidant and antimicrobial activities of $B$. aereus}

Antioxidant capacity was investigated by four in vitro tests that determined reducing power, free radicals scavenging activity and lipid peroxidation inhibition of the $B$. aereus methanolic extract (Table 3). Analyzing the results obtained for antioxidant activity, B. aereus revealed a concentration of total phenolics of $31.00 \mathrm{mg} \mathrm{GAE} / \mathrm{g}$ extract, indicating a good potential of reducing capacity. The $\mathrm{EC}_{50}$ values for all the tests ranged from $0.33 \mathrm{mg} / \mathrm{mL}$ to $3.29 \mathrm{mg} / \mathrm{mL}$. The extract possessed the best potential in lipid peroxidation inhibition, using TBARS assay, where the $\mathrm{EC}_{50}$ value was $0.33 \mathrm{mg} / \mathrm{mL}$. The lowest potential was observed in free radical scavenging activity, tested with DPPH, with $\mathrm{EC}_{50}$ value of $3.29 \mathrm{mg} / \mathrm{mL}$. Total phenolics content in $B$. aereus previously studied was higher in comparison to our sample and was $46.05 \mathrm{GAE} / \mathrm{g}$ extract. Also, radical scavenging capacity of the sample from Portugal previously studied was higher $(0.25 \mathrm{mg} / \mathrm{mL})$, as well as reducing power $(0.47 \mathrm{mg} / \mathrm{mL})$ (Heleno et al. 2011). The observed antioxidant activity may be the consequence of the presence of different molecules with antioxidant potential, described in the previous section, such as tocopherols, organic acids and phenolic compounds.

Antimicrobial activity of $B$. aereus methanolic extract was assessed by microdilution method, and the results were presented as MIC and MBC/MFC in Table 4. The most sensitive bacterial species to B.aereus methanolic extract was $S$. aureus with the MIC of $0.40 \mathrm{mg} / \mathrm{mL}$ and MBC of $1.50 \mathrm{mg} / \mathrm{mL}$. $M$. flavus, L. monocytogenes and E. coli were the most resistant strains to the effect of $B$. aereus extract with MIC of $3.00 \mathrm{mg} / \mathrm{mL}$ and $\mathrm{MBC}$ of $6.00 \mathrm{mg} / \mathrm{mL}$. It might be suggested that the antimicrobial activity of the extract is dependent on the bacterial species used rather than on difference in cell wall structure of the tested bacteria. Regarding antifungal activity, A. ochraceus was the most susceptible micromycete with MIC of $0.001 \mathrm{mg} / \mathrm{mL}$ and $\mathrm{MFC}$ of $0.400 \mathrm{mg} / \mathrm{mL}$. $P$. aurantiogriseum was the most resistant strain with MIC of $3.00 \mathrm{mg} / \mathrm{mL}$ and $\mathrm{MBC}$ of $6.00 \mathrm{mg} / \mathrm{mL}$.

In general, fungi were more sensitive than bacteria to the effect of $B$. aereus methanolic extract. Positive controls namely, standard antibiotics (streptomycin and ampicillin) and antimycotics (bifonazole and ketoconazole) were used, but the comparison with B. aereus extract should be avoided, since the extract presents a mixture of compounds and standard drugs are single molecules. Standard drugs were used for validation of the method as positive controls, rather than for the comparison with the extract. To our best knowledge, antimicrobial activity, regarding antibacterial and antifungal potentials of $B$. aereus methanolic extract, was not previously investigated. Mushroom species are recently and intensively investigated for their antifungal (Alves et al. 2013) activities, reporting interesting potential of various species with higher or lower MIC and $\mathrm{MBC} / \mathrm{MFC}$ values than the ones obtained in this study.

\section{In situ meat preserving properties}

To avoid undesirable sensory changes, toxicity and other harmful and undesirable characteristics, application of low amounts of naturally occurring antimicrobial agents as ingredients should be also explored, in order to control spoilage. The consumption of more food that has been formulated with chemical preservatives has increased
Table 3 Antioxidant properties of Boletus aereus methanolic extract (mean $\pm \mathrm{SD})$

\begin{tabular}{lrr}
\hline & Boletus aereus & Trolox \\
\hline Folin- Ciocalteu assay (mg GAE/g extract) & $31.00 \pm 3.62$ & - \\
Ferricyanide/Prussian blue assay $\left(\mathrm{EC}_{50} ; \mathrm{mg} / \mathrm{mL}\right)$ & $0.75 \pm 0.01$ & $0.04 \pm 0.00$ \\
DPPH scavenging activity $\left(\mathrm{EC}_{50} ; \mathrm{mg} / \mathrm{mL}\right)$ & $3.29 \pm 0.05$ & $0.03 \pm 0.00$ \\
$\beta$-carotene/linoleate assay $\left(\mathrm{EC}_{50} ; \mathrm{mg} / \mathrm{mL}\right)$ & $2.89 \pm 0.58$ & $0.003 \pm 0.00$ \\
TBARS assay $\left(\mathrm{EC}_{50} ; \mathrm{mg} / \mathrm{mL}\right)$ & $0.33 \pm 0.27$ & $0.004 \pm 0.00$ \\
\hline
\end{tabular}


Table 4 In vitro antimicrobial activity of Boletus aereus methanolic extract

\begin{tabular}{llcc}
\hline Bacteria & $\begin{array}{c}\text { Boletus aereus } \\
\text { MIC/MBC } \\
(\mathrm{mg} / \mathrm{mL})\end{array}$ & $\begin{array}{c}\text { Streptomycin } \\
\text { MIC/MBC } \\
(\mathrm{mg} / \mathrm{mL})\end{array}$ & $\begin{array}{c}\text { Ampicillin } \\
\text { MIC/MBC } \\
(\mathrm{mg} / \mathrm{mL})\end{array}$ \\
Staphylococcus aureus & $0.40 / 1.50$ & $0.04 / 0.09$ & $0.25 / 0.37$ \\
Bacillus cereus & $1.50 / 3.00$ & $0.09 / 0.17$ & $0.25 / 0.37$ \\
Micrococcus flavus & $3.00 / 6.00$ & $0.17 / 0.34$ & $0.25 / 0.37$ \\
Listeria monocytogenes & $3.00 / 6.00$ & $0.17 / 0.34$ & $0.37 / 0.49$ \\
Pseudomonas aeruginosa & $1.50 / 3.00$ & $0.17 / 0.34$ & $0.74 / 1.24$ \\
Salmonella Typhimurium & $0.75 / 1.50$ & $0.17 / 0.34$ & $0.37 / 0.49$ \\
Escherichia coli & $3.00 / 6.00$ & $0.17 / 0.34$ & $0.25 / 0.49$ \\
Enterobacter cloacae & $1.50 / 3.00$ & $0.26 / 0.52$ & $0.37 / 0.74$ \\
Fungi & Boletus aereus & Bifonazole & Ketoconazole \\
& MIC/MFC & MIC/MFC & MIC/MFC \\
Aspergillus fumigatus & $(\mathrm{mg} / \mathrm{mL})$ & $(\mathrm{mg} / \mathrm{mL})$ & $0.20 / 0.50$ \\
Aspergillus versicolor & $0.40 / 3.00$ & $0.15 / 0.20$ & $0.20 / 0.50$ \\
Aspergillus ochraceus & $0.006 / 0.400$ & $0.10 / 0.20$ & $1.50 / 2.00$ \\
Aspergillus niger & $0.001 / 0.400$ & $0.15 / 0.20$ & $0.20 / 0.50$ \\
Trichoderma viride & $1.50 / 3.00$ & $0.15 / 0.20$ & $1.00 / 1.00$ \\
Penicillium funiculosum & $0.025 / 0.400$ & $0.15 / 0.20$ & $0.20 / 0.50$ \\
Penicillium ochrochloron & $0.75 / 1.50$ & $0.20 / 0.25$ & $2.50 / 3.50$ \\
Penicillium aurantiogriseum & $1.50 / 3.00$ & $0.20 / 0.25$ & $0.20 / 0.30$ \\
\hline
\end{tabular}

consumer concern and created a demand for more natural and minimally processed food. As a result, there has been a great interest in naturally produced antimicrobial agents (Cleveland et al. 2001). L. monocytogenes, S. aureus, Salmonella spp. and some $E$. coli are known as common foodborne pathogenic bacteria and are frequently isolated from meat and meat products (Borch and Arinder 2002). Outbreaks of Salmonella Typhimurium in meat products are well documented (Evans et al. 1999).

The experiment with inoculating meat was monitored for 7 days. On the 1 th, 4 th and 7 th day GIC $_{50}$ values were calculated for meat stored at $+4{ }^{\circ} \mathrm{C}$ and $+25^{\circ} \mathrm{C}$. From Table 5 it is evident that methanolic extract of $B$. aereus showed better control of microbial growth when applied in combination with lower temperature $\left(+4{ }^{\circ} \mathrm{C}\right)$. $S$. aureus was the most sensitive bacterium to the extract effect, followed by $S$. Typhimurium and $E$. coli, while the most resistant strain was L. monocytogenes. It is evident that $\mathrm{GIC}_{50}$ values increased during the days of storage, indicating higher concentration of the extracts as necessary for the control of bacterial growth in pork meat.

Table 5 In situ antimicrobial activity of Boletus aereus in pork meat medium, GIC $_{50}$ in $\mathrm{mg} / \mathrm{mL}$
Determination of $\mathrm{GIC}_{50}$ could be used as interesting tool to measure the inhibition of bacteria in liquid foods by natural antimicrobial preservatives. The control samples in microtiter plates could grow up to $10^{8} \mathrm{CFU} / 100 \mu \mathrm{L}$ of medium, as we have checked by serial dilutions and cultivation of cells on laboratory agar broths. From this observation if we have calculation that bacterium was in concentration of $10^{8}$ in control sample (100\% growth) and if we have inhibition of $95 \%$ in our experimental well (5\% growth), it means that there are still bacteria in experimental well in concentration of $5 \times 10^{6}$. This value could be read spectrophotometrically, since spectrophotometric measures are capable of being determined just with the cells of $10^{6}$ or more. It is not surprising that the results slightly differ from those obtained by microdilution method. Of course $100 \%$ inhibition does not obligatory mean that bacterium was killed. The extract had microbicidal activity at high concentrations, which was checked by subcultivation of bacterium. Thus, the method was developed for validating inhibitory activities of natural preservatives in liquid foods and for the determination of $\mathrm{GIC}_{50}$ value.

\begin{tabular}{llll}
\hline Bacteria & 1th day $25{ }^{\circ} \mathrm{C} / 4{ }^{\circ} \mathrm{C}$ & 4th day $25{ }^{\circ} \mathrm{C} / 4{ }^{\circ} \mathrm{C}$ & 7 th day $25{ }^{\circ} \mathrm{C} / 4{ }^{\circ} \mathrm{C}$ \\
\hline Staphylococcus aureus & $1.03 / 0.40$ & $1.21 / 0.48$ & $1.45 / 0.54$ \\
Listeria monocytogenes & $2.78 / 1.81$ & $2.83 / 1.92$ & $2.99 / 2.11$ \\
Escherichia coli & $1.56 / 1.48$ & $1.66 / 1.52$ & $1.67 / 1.57$ \\
Salmonella Typhimurium & $0.94 / 0.70$ & $1.01 / 0.75$ & $1.10 / 0.78$ \\
\hline
\end{tabular}




\section{Conclusions}

This research highlights $B$. aereus as good source of bioactive compounds such as fatty acids, tocopherols, organic acids and phenolic compounds. Furthermore, its methanolic extract possessed antioxidant and antimicrobial activities in vitro. Research findings from this work provide a basis for developing effective naturally occurring antimicrobial agent to extend shelf life of meat product and perhaps other types of traditional food products. The present study provided strong evidence that $B$. aereus extract could be used as effective controlling agent of microbial growth in pork meat.

Acknowledgments The authors are grateful to Foundation for Science and Technology (FCT, Portugal) and COMPETE/QREN/EU for financial support to CIMO strategic project PEst-OE/AGR/UI0690/2011 and L. Barros contract. The authors also thank to Serbian Ministry of Education, Science and Technological Development for financial support (grant number 173032). The authors kindly thank to Nada Lazic for the harvest of the Boletus aereus sample.

\section{References}

Alves MJ, Ferreira ICFR, Dias J, Teixeira V, Martins A, Pintado M (2013) A review on antifungal activity of mushroom (basidiomycetes) extracts and isolated compounds. Curr Top Med Chem 13:2648-2659

AOAC (1995) Official methods of analysis, 16th edn. Association of Official Analytical Chemists, Arlington

Barros L, Pereira C, Ferreira ICFR (2013) Optimized analysis of organic acids in edible mushrooms from Portugal by ultra fast liquid chromatography and photodiode array detection. Food Anal Methods 6:309-316

Borch E, Arinder P (2002) Bacteriological safety issues in red meat and ready-to-eat meat products, as well as control measures. Meat Sci 62:381-390

Bukvički D, Stojković D, Soković M, Vannini L, Montanari C, Pejin B, Savic A, Veljic M, Grujic S, Marin PD (2014) Satureja horvatii essential oil: in vitro antimicrobial and antiradical properties and in situ control of Listeria monocytogenes in pork meat. Meat Sci 96: $1355-1360$

Carocho M, Ferreira ICFR (2013) A review on antioxidants, prooxidants and related controversy: natural and synthetic compounds, screening and analysis methodologies and future perspectives. Food Chem Toxicol 51:15-25

Cleveland J, Montville TJ, Nes IF, Chikindas ML (2001) Bacteriocins: safe, natural antimicrobials for food preservation. Int J Food Microbiol 71:1-20

CLSI. Clinical and Laboratory Standards Institute (2009) Methods for dilution antimicrobial susceptibility tests for bacteria that grow aerobically. Approved standard, 8th edn. CLSI publication M07-A8. Clinical and Laboratory Standards Institute, Wayne

Evans MR, Salmon RL, Nehaul L, Mably S, Wafford L, Nolan-Farrell MZ, Gardner D, Ribeiro CD (1999) An outbreak of Salmonella typhimurium DT170 associated with kebab meat and yogurt relish. Epidemiol Infect 122:377-383

Ferreira ICFR, Barros L, Abreu RMV (2009) Antioxidants in wild mushrooms. Curr Med Chem 16:1543-1560

Franz CMAP, Cho G-S, Holzapfel WH, Gálvez A (2010) Safety of Lactic Acid Bacteria. In: Mozzi F, Raya RR, Vignolo GM (eds)
Biotechnology of Lactic Acid Bacteria: Novel Applications. Wiley, Oxford, pp 341-59

Hadžić I (2012) Priručnik za branje jestivih i lekovitih gljiva. Edicija, Belgrade, Serbia

Hanuš LO, Shkrob I, Dembitsky VM (2008) Lipids and fatty acids of wild edible mushrooms of the genus Boletus. J Food Lipids 15:370-383

Heleno SA, Barros L, Sousa MJ, Martins A, Ferreira ICFR (2009) Study and characterization of selected nutrients in wild mushrooms from Portugal by gas chromatography and high performance liquid chromatography. Microchem J 93:195-199

Heleno SA, Barros L, Sousa MJ, Martins A, Ferreira ICFR (2010) Tocopherols composition of Portuguese wild mushrooms with antioxidant capacity. Food Chem 119:1443-1450

Heleno SA, Barros L, Sousa MJ, Martins AM, Santos-Buelga C, Ferreira ICFR (2011) Targeted metabolites analysis in wild Boletus species. LWT Food Sci Technol 44:1343-1348

Hensley K, Benaksas EJ, Bolli R, Comp P, Grammas P, Hamdheydari L et al (2004) New perspectives on vitamin E: gamma-tocopherol and carboxyelthylhydroxychroman metabolites in biology and medicine. Free Radic Biol Med 36:1-15

Kalač P (2013) A review of chemical composition and nutritional value of wild-growing and cultivated mushrooms. J Sci Food Agric 93:209-218

Kris-Etherton PM (1999) Monounsaturated fatty acids and risk of cardiovascular disease. Circulation 100:1253-1258

Morris MC, Schneider JA, Li H, Tangney CC, Nag S, Bennett DA, Honer WG, Barnes LL (2014) Brain tocopherols related to Alzheimer's disease neuropathology in humans. Alzheimers Dement S1552-5260(13):02942-7

Popović V, Živković J, Davidović S, Stevanović M, Stojković D (2013) Mycotherapy of cancer: an update on cytotoxic and antitumor activities of mushrooms, bioactive principles and molecular mechanisms of their action. Curr Top Med Chem 13:2791-2806

Reis FS, Stojković D, Soković M, Glamočlija J, Cirić A, Barros L, Ferreira ICFR (2012a) Chemical characterization of Agaricus bohusii, antioxidant potential and antifungal preserving properties when incorporated in cream cheese. Food Res Int 48:620-626

Reis FS, Martins A, Barros L, Ferreira ICFR (2012b) Antioxidant properties and phenolic profile of the most widely appreciated cultivated mushrooms: a comparative study between in vivo and in vitro samples. Food Chem Toxicol 50:1201-1207

Ren L, Perera C, Hemar Y (2012) Antitumor activity of mushroom polysaccharides: a review. Food Funct 3:1118-1130

Stojković D, Reis FS, Barros L, Glamočlija J, Cirić A, van Griensven LJLD, Soković M, Ferreira ICFR (2013a) Nutrients and non-nutrients composition and bioactivity of wild and cultivated Coprinus comatus (O.F.Müll.) Pers. Food Chem Toxicol 59:289-296

Stojković D, Reis FS, Ferreira ICFR, Barros L, Glamočlija J, Ćirić A, Nikolić M, Stević T, Giweli A, Soković M (2013b) Tirmania pinoyi: chemical composition, in vitro antioxidant and antibacterial activities and in situ control of Staphylococcus aureus in chicken soup. Food Res Int 53:56-62

Stojković DS, Barros L, Calhelha RC, Glamočlija J, Ćirić A, Van Griensven LJLD, Soković M, Ferreira ICFR (2014a) A detailed comparative study between chemical and bioactive properties of Ganoderma lucidum from different origins. Int J Food Sci Nutr 65:42-47

Stojković D, Reis FS, Glamoclija J, Ciric A, Barros L, Van Griensven LJLD, Ferreira ICFR, Sokovic M (2014b) Cultivated strains of Agaricus bisporus and A. brasiliensis: chemical characterization and evaluation of antioxidant and antimicrobial properties for final healthy product - natural preservatives in yoghurt. Food Funct 5:1602-1612 